\title{
Impact of weight reduction program on serum alanine aminotransferase activity and immunologic response in obese hepatitis B patients.
}

\author{
Shehab Mahmoud Abd El- Kader ${ }^{1}$, Mohammed H Saiem Al-Dahr²
}

1. Department of Physical Therapy, Faculty of Applied Medical Sciences, King Abdulaziz University, Jeddah, Saudi Arabia.

2. Department of Medical Laboratory Technology, Faculty of Applied Medical Sciences, King Abdulaziz University, Jeddah, Saudi Arabia.

\begin{abstract}
Background: Globally, chronic B viral hepatitis (HBV) is a major health problem. Obesity is a common problem among patients with HBV. Several studies have reported that obesity is an important risk factor that alters immune system response in individuals with no underlying cause of liver disease. However, there is a strong association between BMI and the human immune system among HBV patients.

Objective: This study was to examine the correlation between body mass index, serum alanine aminotransferase activity (ALT) and immunologic response in obese hepatitis B patients.

Material and methods: One hundred fifty male patients with chronic hepatitis B virus, their age ranged from 30 to 45 (38.64 \pm 7.12) years and their BMI ranged from $30-35 \mathrm{~kg} / \mathrm{m}^{2}$. All Subjects were included in two groups: The first group received weight reduction program in the form of treadmill aerobic exercises in addition to diet control whereas the second group received no therapeutic intervention. Parameters of serum alanine aminotransferase (ALT), CD3, CD4 and CD8 were quantified; Leukocyte, differential counts and body mass index (BMI) were measured before and after 3 months at the end of the study.

Results: There was a $24.7 \%, 36.8 \%, 30.8 \%, 40.7 \%, 28.6 \%, 25.9 \%, 33.3 \%$ and $14.3 \%$ reduction in mean values of alanine aminotransferase (ALT), white blood cells, total neutrophil count, monocytes, CD3, CD4,CD8 and BMI respectively in group (A) at the end of the study. In addition, there were significant differences between mean levels of the investigated parameters in groups. Conclusion: Based on our findings, weight loss modulates serum alanine aminotransferase and immune system parameters of patients with hepatitis B virus infection.
\end{abstract}

Keywords: Hepatitis B virus, obesity, immune system, weight reduction.

DOI: http://dx.doi.org/10.4314/ahs.v16i1.17

Cita as: Abd El-Kader SM, Al-Dabr MHS. Impact of weight reduction program on serum alanine aminotransferase activity and immunologic response in obese hepatitis B patients. Afri Health Sci. 2016;16(1): 128-134. bttp:// dx.doi.org/10.4314/abs.v16i1.17

\section{Introduction}

Hepatitis B virus (HBV) causes inflammation of the liver in humans and is a major public health problem worldwide. About a quarter of the world population $(>2$ bil

\section{Corresponding author:}

Shehab M. Abd El-Kader,

Department of Physical Therapy,

Faculty of Applied Medical Sciences,

King Abdulaziz University, Jeddah, Saudi Arabia.

P.O. Box 80324, Jeddah, 21589, Saudi Arabia.

Phone: +966-569849276

E. mail: salmuzain@kau.edu.sa lion) has been infected with $\mathrm{HBV}$, including 350 million with chronic or lifelong HBV infection ${ }^{1}$. HBV is $50-100$ times more infectious than human immuno-deficiency virus $(\mathrm{HIV})^{2,3}$.

HBV carriers are at risk of developing life threatening cirrhosis and later on hepatic carcinoma. The long-term aim in the treatment of these patients is to prevent the development of cirrhosis and hepatocellular carcinoma ${ }^{4}$. The immune responses to $\mathrm{HBV}$ antigens are responsible both for viral clearance during acute infection and for disease pathogenesis. Immune responses involved in viral clearance comprise both humoral and cellular immunity where CD4+ helper $\mathrm{T}$ cells contribute to generation of antibodies against viral envelope antigens that clear circu- 
lating viral particles and $\mathrm{CD} 8+$ cytotoxic $\mathrm{T}$ lymphocytes eliminate infected cells ${ }^{5}$.

Obesity is a major health problem since excessive body weight constitutes a risk factor in a number of chronic diseases. The prevalence of obesity is increasing worldwide and as per the latest WHO estimates, approximately 500 million adults and nearly forty three million children under the age of 5 years appear to be obese, showing a $\mathrm{BMI} \geq 30 \mathrm{~kg} / \mathrm{m}^{26}$. Immune-competence is dependent on nutritional status and can be easily dysregulated in states of imbalanced nutrition such as under nutrition (malnutrition) or over nutrition (obesity). However, immune suppression in undernourished state is well known? ${ }^{7}$.

Many authors reported dysregulation and alteration in number of immune cells in obese subjects. Obese subjects showed either increased or decreased total lymphocytes in peripheral blood populations $\mathrm{s}^{8-11}$ and had decreased CD8 $+\mathrm{T}$ cell population along with increased or decreased $\mathrm{CD} 4+\mathrm{T}$ cells ${ }^{10,11}$. Therefore, the purpose of this study was to examine the correlation between body mass index, serum alanine aminotransferase (ALT) activity and immunologic response in obese HBV patients.

As there is limitation in studies reporting the benefits of lifestyle modification on immune system response among patients with HBV, this study aimed to examine effects of weight reduction program on selected immune parameters among $\mathrm{HBV}$ patients.

\section{Patients and methods \\ Subjects}

One hundred fifty male patients with chronic hepatitis B; their age ranged from 30 to 45 (38.64 \pm 7.12$)$ years and their BMI ranged from $30-35 \mathrm{~kg} / \mathrm{m}^{2}$, were studied on referral to Gastroenterology and Hepatology Department, King Abdulaziz University Teaching Hospital, Saudi Arabia. Only patients diagnosed with chronic HBV monoinfection had undergone Real-Time polymerase chain reaction. The inclusion criteria was as follows: Positive test for serum hepatitis B surface antigen ( $\mathrm{HBs} A g$ ), negative for $\mathrm{HBeAg}$ for at least six months, elevated serum ALT level recorded at least 2 distinct instances at an interval of one month, and HBV DNA level > $2000 \mathrm{IU} / \mathrm{mL}$ (CobasAmplicor HBV monitor, which has a detection limit of $12 \mathrm{IU} / \mathrm{mL}$ ). Anti-viral treatment for all enrolled pa- tients followed the American Association for the Study of Liver Disease (AASLD) treatment guidelines ${ }^{12}$.

The exclusion criteria was as follows: patients with hepatitis $\mathrm{C}$ virus, alcoholic liver disease and radiologic evidence of hepatitis C cirrhosis (HCC). The Scientific Research Ethical Committee, Faculty of Applied Medical Sciences at King Abdulaziz University, approved this study. All participants were free to withdraw from the study at any time. Patients were randomly divided in to two equal groups: Group A included 75 patients who received weight reduction program in the form of treadmill aerobic exercises in addition to diet control, whereas group B received no therapeutic intervention.

\section{Measurements}

All measurements indicated below were taken before the beginning of the study and after 3 months at the end of the study.

A. Flow cytometry analysis: The human leukocyte differentiation antigens CD3, CD4 and CD8 (Beckman Coulter, Marseille, France) five microliters of appropriate monoclonal antibody was added to $50 \mu \mathrm{L}$ of a whole blood sample and incubated for 15 minutes at room temperature. Thereafter, the erythrocytes were lysed with 125 $\mu \mathrm{L}$ of a lysing solution, OptiLyse $\mathrm{C}$, for 10 minutes. The reaction stopped by the addition of $250 \mu \mathrm{L}$ phosphatebuffered saline. The samples analyzed by flow cytometry using Cytomics FC500 and CXP software (Beckman Coulter). The leukocyte subsets were defined by forwardand side-scatter pattern. A fluorescence background and antibody-nonspecific staining determined the negative control value.

B. Analysis of peripheral blood cells: The analysis of peripheral blood cells (e.g., total and differential count) was performed on a Beckman Coulter AcT 5 diff hematology analyzer. The values were expressed in percentages and absolute numbers.

\section{Serum alanine aminotransferase and (ALT) viral} serology tests: Blood samples were collected from the antecubital vein. Subjects had blood drawn at the same time in the morning on each occasion (between 8 and 10 AM). Subjects lay supine for $10 \mathrm{~min}$ prior to the blood 
collection. $10 \mathrm{ml}$ of blood was drawn into a tube containing few milliliters of sodium citrate; plasma was separated from the blood by centrifugation $(120 \times \mathrm{g}$ for 15 $\mathrm{min})$ at room temperature. Serum alanine aminotransferasewas measured by the colorimetric enzymatic method using an automatic spectrophotometer (Bioclin, Quibasa, Belo Horizonte, MG, Brazil). All samples were assayed in duplicate, and the mean of the paired results was determined. In addition, serum samples were tested for the presence of $\mathrm{HBsAg}, \mathrm{HBeAg}$, and anti-HBeAg antibody using radioimmunoassay (Abbott Laboratories, North Chicago, IL), while a CobasAmplicor HBV monitor determined the HBV DNA.

D. Body mass index (BMI): Weight and height scale (Metrotype -England) was used to measure weight and height to calculate the body mass index (BMI). Body mass index was calculated by dividing the weight in kilograms by the square of the height in meters $\left(\mathrm{Kg} / \mathrm{m}^{2}\right)$. According to the WHO classification, a BMI of $<18.5 \mathrm{~kg} / \mathrm{m}^{2}$ is under weight, $18.5-24.9 \mathrm{~kg} / \mathrm{m}^{2}$ is normal $25-29.9 \mathrm{~kg} / \mathrm{m}^{2}$ is overweight. A BMI of $>30 \mathrm{~kg} / \mathrm{m}^{2}$ is classified as obese and this group was further divided into moderate obesity (30-34.9 $\left.\mathrm{kg} / \mathrm{m}^{2}\right)$, severe obesity $\left(35-39.9 \mathrm{~kg} / \mathrm{m}^{2}\right)$ and very severe obesity $\left(\leq 40 \mathrm{~kg} / \mathrm{m}^{2}\right)^{13}$.

\section{Procedures}

Following the previous evaluation, all patients were divided randomly into the following groups:

1. The training group (Group A): Were submitted to the aerobic exercise training to complete a 12 -weeks treadmill aerobic exercise (Enraf Nonium, Model display panel Standard, NR 1475.801, Holland) which was con- ducted according to recommendation of aerobic exercise application approved by the American College of Sports Medicine ${ }^{14}$. Training program included 5 minutes for warming-up in the form of range motion and stretching exercises, 30 minutes of aerobic exercise training with intensity equal $60-70 \%$ of the individual maximum heart rate followed by cooling down for 10 minutes (on treadmill with low speed and without inclination). Participants had 3 sessions / week for 3 months with close supervision of physical therapist. In addition, a dietician performed an interview-based food survey for all participants of group (A) for detection of feeding habits, abnormal dietary behavior and to prescribe the balanced low caloric $\operatorname{diet}^{15}$, that provided 1200 kilocalories/day for 12 weeks. The same dietician continuously monitored all participant caloric intakes through reviewing the detailed record of food intake every 2 weeks ${ }^{16,17}$.

\section{Statistical analysis}

The mean values of the investigated parameters obtained before and after three months in both groups compared, using paired " $\mathrm{t}$ " test. Independent " $\mathrm{t}$ " test was used for the comparison between the two groups $(\mathrm{P}<0.05)$.

\section{Results}

The two groups were considered homogeneous regarding the demographic variables (Table 1). The mean age for group, (A) was 38.13 \pm 5.81 years, and the mean age of the group (B) was $36.84 \pm 6.16$ years. There was no significant differences in body mass index (BMI), fasting glucose, triglyceride, total cholesterol, high-density lipoprotein-cholesterol (HDL), systolic, diastolic blood pressure and HBV viral load between both groups.

Table 1: Comparison of clinical data between HBV patients in both groups.

\begin{tabular}{|l|c|c|}
\hline & Group (A) & Group (B) \\
\hline Age (year) & $38.13 \pm 5.81$ & $36.84 \pm 6.16$ \\
\hline BMI $\left(\mathrm{kg} / \mathrm{m}^{2}\right)$ & $31.65 \pm 4.12$ & $30.41 \pm 5.25$ \\
\hline Fasting glucose (mg/dL) & $100.43 \pm 10.28$ & $97.92 \pm 9.67$ \\
\hline Triglyceride $(\mathrm{mg} / \mathrm{dL})$ & $131.31 \pm 13.70$ & $128.11 \pm 11.54$ \\
\hline Total cholesterol $(\mathrm{mg} / \mathrm{dL})$ & $193.27 \pm 18.06$ & $191.76 \pm 16.18$ \\
\hline HDL-C $(\mathrm{mg} / \mathrm{dL})$ & $48.75 \pm 8.92$ & $50.13 \pm 9.16$ \\
\hline Systolic blood pressure $(\mathrm{mm} \mathrm{Hg})$ & $118.14 \pm 15.13$ & $115.88 \pm 16.10$ \\
\hline Diastolic blood pressure $(\mathrm{mm} \mathrm{Hg})$ & $76.93 \pm 6.38$ & $75.11 \pm 5.76$ \\
\hline HBV DNA $(\mathrm{IU} / \mathrm{mL})$ & $3.57 \pm 0.85 \times 10^{6}$ & $3.32 \pm 0.78 \times 10^{6}$ \\
\hline
\end{tabular}

BMI: Body Mass Index; HDL-C: High-density lipoprotein-cholesterol. 
There was a $24.7 \%, 36.8 \%, 30.8 \%, 40.7 \%, 28.6 \%, 25.9 \%$, $33.3 \%$ and $14.3 \%$ reduction in mean values of alanine aminotransferase (ALT), white blood cells, total neutrophil count, monocytes, CD3, CD4,CD8 and BMI respectively in group (A) at the end of the study. The mean val- ues of alanine aminotransferase (ALT), white blood cells, total neutrophil count, monocytes, CD3, CD4,CD8 and BMI were significantly decreased in group received aerobic exercise training in addition to diet regimen (Table 2), While the results of group (B) received no treatment intervention were not significant (Table 3).

Table 2: Mean value and significance of body mass index, : alanine aminotransferase, white blood cells, total neutrophil, monocytes, CD3, CD4 and CD8 count of group (A) before and at the end of the study.

\begin{tabular}{|l|c|c|c|c|}
\hline & \multicolumn{2}{|c|}{ Mean + SD } & \multirow{2}{*}{ T-value } & \multirow{2}{*}{ Significance } \\
\cline { 2 - 3 } & $\begin{array}{c}\text { Before the } \\
\text { study }\end{array}$ & $\begin{array}{c}\text { At the end } \\
\text { of the study }\end{array}$ & \multirow{2}{*}{ T-vin } \\
\hline BMI $\left(\mathrm{kg} / \mathrm{m}^{2}\right)$ & $31.65 \pm 4.12^{*}$ & $27.13 \pm 3.74$ & 8.16 & $\mathrm{P}<0.05$ \\
\hline ALT activity $(\mathrm{IU} / \mathrm{L})$ & $74.23 \pm 5.68^{*}$ & $55.87 \pm 4.54$ & 6.81 & $\mathrm{P}<0.05$ \\
\hline $\begin{array}{l}\text { White blood cells } \\
\text { count }\left(10^{9} / \mu \mathrm{L}\right)\end{array}$ & $8.94 \pm 2.97^{*}$ & $5.65 \pm 2.53$ & 8.12 & $\mathrm{P}<0.05$ \\
\hline $\begin{array}{l}\text { Total neutrophil count } \\
\left(10^{9} / \mu \mathrm{L}\right)\end{array}$ & $6.23 \pm 1.86^{*}$ & $4.31 \pm 1.54$ & 7.53 & $\mathrm{P}<0.05$ \\
\hline Monocytes $\left(10^{9} / \mu \mathrm{L}\right)$ & $0.54 \pm 0.14^{*}$ & $0.32 \pm 0.12$ & 5.74 & $\mathrm{P}<0.05$ \\
\hline $\mathrm{CD} 3$ count $\left(10^{9} / \mathrm{L}\right)$ & $1.71 \pm 0.82^{*}$ & $1.22 \pm 0.61$ & 6.43 & $\mathrm{P}<0.05$ \\
\hline $\mathrm{CD} 4$ count $\left(10^{9} / \mathrm{L}\right)$ & $1.43 \pm 0.61^{*}$ & $1.06 \pm 0.52$ & 6.18 & $\mathrm{P}<0.05$ \\
\hline $\mathrm{CD} 8$ count $\left(10^{9} / \mathrm{L}\right)$ & $0.78 \pm 0.17^{*}$ & $0.52 \pm 0.11$ & 5.36 & $\mathrm{P}<0.05$ \\
\hline
\end{tabular}

BMI= Body Mass Index; ALT: alanine aminotransferase; $(*)$ indicates a significant difference between the two groups, $\mathrm{P}<0.05$.

Table 3: Mean value and significance of body mass index, : alanine aminotransferase, white blood cells, total neutrophil, monocytes, CD3, CD4 and CD8 count of group (B) before and at the end of the study.

\begin{tabular}{|l|c|c|c|c|}
\hline & \multicolumn{2}{|c|}{ Mean + SD } & \multirow{2}{*}{ T-value } & \multirow{2}{*}{ Significance } \\
\cline { 2 - 3 } & $\begin{array}{c}\text { Before the } \\
\text { study }\end{array}$ & $\begin{array}{c}\text { At the end } \\
\text { of the study }\end{array}$ & \\
\hline BMI $\left(\mathrm{kg} / \mathrm{m}^{2}\right)$ & $30.41 \pm 5.25$ & $30.93 \pm 5.27$ & 0.732 & $\mathrm{P}>0.05$ \\
\hline ALT activity(IU/L) & $73.81 \pm 4.82$ & $76.26 \pm 4.91$ & 0.815 & $\mathrm{P}>0.05$ \\
\hline $\begin{array}{l}\text { White blood cells } \\
\text { count }\left(10^{9} / \mu \mathrm{L}\right)\end{array}$ & $8.86 \pm 2.67$ & $9.15 \pm 2.74$ & 0.693 & $\mathrm{P}>0.05$ \\
\hline $\begin{array}{l}\text { Total neutrophil count } \\
\left(10^{9} / \mu \mathrm{L}\right)\end{array}$ & $5.91 \pm 1.73$ & $6.16 \pm 1.81$ & 0.712 & $\mathrm{P}>0.05$ \\
\hline Monocytes $\left(10^{9} / \mu \mathrm{L}\right)$ & $0.51 \pm 0.12$ & $0.54 \pm 0.16$ & 0.461 & $\mathrm{P}>0.05$ \\
\hline $\mathrm{CD} 3$ count $\left(10^{9} / \mathrm{L}\right)$ & $1.63 \pm 0.71$ & $1.70 \pm 0.78$ & 0.355 & $\mathrm{P}>0.05$ \\
\hline $\mathrm{CD} 4$ count $\left(10^{9} / \mathrm{L}\right)$ & $1.38 \pm 0.57$ & $1.43 \pm 0.52$ & 0.298 & $\mathrm{P}>0.05$ \\
\hline $\mathrm{CD} 8$ count $\left(10^{9} / \mathrm{L}\right)$ & $0.69 \pm 0.13$ & $0.73 \pm 0.18$ & 0.267 & $\mathrm{P}>0.05$ \\
\hline
\end{tabular}

BMI= Body Mass Index; $\left.\quad{ }^{*}\right)$ indicates a significant difference between the two groups, $\mathrm{P}<0.05$. 
Table 4: Mean value and significance of body mass index, : alanine aminotransferase, white blood cells, total neutrophil, monocytes, CD3, CD4 and CD8 count of group (A) and group (B) at the end of the study.

\begin{tabular}{|l|c|c|c|c|}
\hline & \multicolumn{2}{|c|}{ Mean + SD } & \multirow{2}{*}{ T-value } & \multirow{2}{*}{ Significance } \\
\cline { 2 - 3 } & Group $(\mathrm{A})$ & Group $(\mathrm{B})$ & & \\
\hline BMI $\left(\mathrm{kg} / \mathrm{m}^{2}\right)$ & $27.13 \pm 3.74$ & $30.93 \pm 5.27$ & 7.12 & $\mathrm{P}<0.05$ \\
\hline ALT activity(IU/L) & $55.87 \pm 4.54$ & $76.26 \pm 4.91$ & 6.10 & $\mathrm{P}<0.05$ \\
\hline $\begin{array}{l}\text { White blood cells } \\
\text { count }\left(10^{9} / \mu \mathrm{L}\right)\end{array}$ & $5.65 \pm 2.53$ & $9.15 \pm 2.74$ & 7.21 & $\mathrm{P}<0.05$ \\
\hline $\begin{array}{l}\text { Total neutrophil count } \\
\left(10^{9} / \mu \mathrm{L}\right)\end{array}$ & $4.31 \pm 1.54$ & $6.16 \pm 1.81$ & 6.42 & $\mathrm{P}<0.05$ \\
\hline Monocytes $\left(10^{9} / \mu \mathrm{L}\right)$ & $0.32 \pm 0.12$ & $0.54 \pm 0.16$ & 4.31 & $\mathrm{P}<0.05$ \\
\hline $\mathrm{CD} 3$ count $\left(10^{9} / \mathrm{L}\right)$ & $1.22 \pm 0.61$ & $1.70 \pm 0.78$ & 5.82 & $\mathrm{P}<0.05$ \\
\hline $\mathrm{CD} 4$ count $\left(10^{9} / \mathrm{L}\right)$ & $1.06 \pm 0.52$ & $1.43 \pm 0.52$ & 5.23 & $\mathrm{P}<0.05$ \\
\hline $\mathrm{CD} 8$ count $\left(10^{9} / \mathrm{L}\right)$ & $0.52 \pm 0.11$ & $0.73 \pm 0.18$ & 4.76 & $\mathrm{P}<0.05$ \\
\hline
\end{tabular}

BMI= Body Mass Index; ALT: Alanine Aminotransferase; $(*)$ indicates a significant difference between the two groups, $\mathrm{P}<0.05$.

\section{Discussion}

The impact of obesity on the immune system is well known and serum alanine aminotransferase (ALT) is elevated among obese HBV patients ${ }^{18 .}$ ALT activity is a commonly used surrogate marker for the evaluation of hepatocellular damage ${ }^{19}$. Several epidemiologic studies have reported that obesity is an important risk factor for elevated ALT activity in individuals with no apparent underlying cause of liver disease ${ }^{20-22}$. A comparable relation between ALT activity and BMI has been observed in a healthy blood donor population ${ }^{23,24}$. It has been reported that high-normal ALT activity predicts insidious, continued liver damage in patients with chronic hepatitis B and it has been speculated that obesity may carry with it a continuum of risk of subtle hepatic injury even in individuals with mild ALT elevation ${ }^{25,26}$. Participants were co-operative and strictly followed the directions of the research team. The main finding of the present study was that, weight-reducing program was associated with significant modulation of ALT, white blood cells, total neutrophil count, monocytes, CD3, CD4 and CD8 in obese patients with HBV as a result of weight loss, these results are in line with many previous studies.
Wasinski and colleagues conducted a study on mice who were submitted to chronic swimming training or a $30 \%$ caloric restriction after consuming a high-fat diet. The mice were subjected to swimming sessions 5 times per week for 6 weeks. Data demonstrated that exercise and caloric restriction modulate resident immune cells in adipose tissues $^{27}$. Carpenter and colleagues evaluated the forced and voluntary exercise as weight-loss treatments in dietinduced obese (DIO) mice and assessed the effects of weight loss on monocyte concentration and cell-surface expression of Toll-like receptor. Results confirmed that short-term exercise and low-fat diet consumption over the 8 weeks caused significant weight loss and altered immune profiles ${ }^{28}$. While, Viardot and colleagues looked at 13 obese people with Type 2 diabetes or pre-diabetes who were limited to a diet of between 1000 and 1600 calories a day for 24 weeks. Gastric banding was performed at 12 weeks to help restrict food intake further. Their results showed an $80 \%$ reduction of pro-inflammatory T-helper cells, as well as reduced activation of other circulating immune cells ( $T$ cells, monocytes and neutrophils) and decreased activation of macrophages in $\mathrm{fat}^{29}$. 
The possible mechanism of immune system modulation by weight reduction could be explained by reduction of adipose tissues which is not only a storage organ, but produces close to 100 cytokines. These secreted adipokines are directly correlated to the increased adipose tissue mass and play an intricate role in various aspects of the innate and adaptive immune response and participate in a wide variety of physiological or physiopathological processes including food intake, insulin sensitivity and inflammation $^{30}$. In addition, weight reduction reduces serum level of leptin. Leptin has pleiotropic effects on immune cell activity as evidenced from the presence of leptin receptors on all immune cells of both the arms of innate and adaptive immunity ${ }^{31}$. However, it should be conceded that the preponderance of men in the sample limits the generalisation of the findings as males are more likely to remain persistently infected with HBV than women. Finally, obese patients with $\mathrm{HBV}$ are recommended to reduce their body weight to improve their liver function and immune system parameters.

\section{Conclusion}

Based on our findings, weight loss modulates serum alanine aminotransferase and immune system parameters of patients with hepatitis B virus infection.

\section{Acknowledgment}

This project was funded by the Deanship of Scientific Research (DSR), King Abdulaziz University, Jeddah, under grant no. (142-5-D1436). The authors, therefore, acknowledge with thanks DSR technical and financial support.

\section{References}

1. WHO. Media Center. Hepatitis B factsheet. WHO Media Center, 2008.

2. Franco E, Bagnato B, Marino MG, Meleleo C, Serino L, Zaratti L. Hepatitis B:Epidemiology and prevention in developing countries. World J Hepatol 2012; 4(3):74-80.

3. Busca A, Kumar A. Innate immune responses in hepatitis B virus (HBV) infection. Busca and Kumar Virology Journal 2014;11:22.

4. Pramoolsinsup C. Management of viral hepatitis B. J Gastroenterol Hepatol 2002; 17(Suppl):S125-S145.

5. Chisari FV, Isogawa M, Wieland SF. Pathogenesis of hepatitis B virus infection. PatholBiol (Paris) 2010;58(4):258-266.

6. WHO. Obesity and overweight fact sheet, 2011.
7. Cyril OE. Complex interactions between malnutrition, infection and immunity: relevance to HIV/AIDS infection. Nigerian Journal of Clinical \& Biomedical Research 2006;1: 6-14.

8. Nieman D, Nehlsen-Cannarella S, Henson D, Butterworth D, Fagoaga O. Immune response to obesity and moderate weight loss. Int J Obes Relat Metab Disord 1996; 20:353-360.

9. Nieman D, Henson D, Nehlsen-Cannarella S, Ekkens M Utter A. Influence of obesity on immune function. $J$ Am Diet Assoc 1999; 99: 294-299.

10. O`Rourke R, Kay T, Scholz M, Diggs B and Jobe B. Alterations in T-cell subset frequency in peripheral blood in obesity. Obes Surg 2005;15: 1463-1468.

11. Tanaka S, Isoda F, Ishihara Y, Kimura M , Yamakawa T. T lymphopaenia in relation to body mass index and TNF-alpha in human obesity: adequate weight reduction can be corrective. ClinEndocrinol (Oxf) 2001;54: 347-354.

12. Lok A, McMahon B.Chronic hepatitis B: update 2009. Hepatology 2009; 50:661-672.

13. Han S, Jeon K, Kim M, Kim H, Lee A. Obesity with a body mass index under 30 does not significantly impair the immune response in young adults. Nutrition Research 2011; 31: 362-369.

14. American College of Sports Medicine. Guidelines for graded exercise testing and exercise prescription, Lea \& Febiger, Philadelphia, 2005.

15. World Health Organization. Diet, Nutrition and the Prevention of Chronic Diseases. London, HMSO (Tech. Rep. Ser., no. 797), 1990.

16. Sciacqua A, Candigliota M, Ceravolo R, Scozzafava A, Sinopoli F, Corsonello A, Sesti G, Perticone F. Weight loss in combination with physical activity improves endothelial dysfunction in human obesity. Diabetes Care 2003; 26: 1673-1678.

17. Murakami T, Horigome H, Tanaka K, Nakata Y, Ohkawara K, Katayama Y, Matsui A. Impact of weight reduction on production of platelet-derived microparticles and fibrinolytic parameters in obesity .Thrombosis Research 2007; 119: 45-53.

18. Wang Y, Lin S, Sheu W, Liu P, Tung K. Obesity and diabetic hyperglycemia were associated with serum alanine aminotransferase activity in patients with hepatitis B infection. Metabolism 2010; 59:486-491.

19. Pratt D, Kaplan M. Evaluation of abnormal liverenzyme results in asymptomatic patients. $N$ Engl J Med 2000;109:588-90.

20. Clark J, brancati F, Diehl A. The prevalence and eti- 
ology of elevated aminotransferase levels in the United States. Am J Gastroenterol 2003; 98:960-7.

21. Erbey J, Silberman C, Lydick E. The prevalence of abnormal serum alanine aminotransferase levels in obese patients and patients with type 2 diabetes. Am J Med 2000; 124:71-9.

22. Ioannou G, Weiss N, Boyko E, Kahn S, Lee S. Contribution of metabolic factors to alanine aminotransferase activity in persons with other causes of liver disease. Gastroenterology 2005; 128: 627-35.

23. Prati D, Taioli E, Zanella A, Della Torre E, Butelli S, Del Vecchio E. Updated definitions of healthy ranges for serum alanine aminotransferase levels. Ann Intern Med 2002; 137:1-10.

24. Piton A, Poynard T, Imbert-Bismut F, Khalil L, Delattre J, Pelissier E. Factors associated with serum alanine transaminase activity in healthy subjects: consequences for the definition of normal values, for selection of blood donors, and for patients with chronic hepatitis C. MULTIVIRC Group. Hepatology 1998; 27:1213-9.

25. Kim H, Nam C, Jee S, Han K, Oh D, Suh I. Normal serum aminotransferase concentration and risk of mortality from liver diseases: prospective cohort study. BMJ 2004; 328:983-6.
26. Yuen M, Yuan H, Wong D, Yuen J, Wong W, Chan A. Prognostic determinants for chronic hepatitis B in Asians: therapeutic implications. Gut 2005; 54:1610-4.

27. Wasinski F, Bacurau RF, Moraes MR, Haro AS, Moraes-Vieira PM, Estrela GR, Paredes-Gamero EJ, Barros CC, Almeida SS, Câmara NO, Araujo RC. Exercise and caloric restriction alter the immune system of mice submitted to a high-fat diet. Mediators Inflamm 2013; 2013:395672.

28. Carpenter KC, Strohacker K, Breslin WL, Lowder TW, Agha NH, McFarlin BK. Effects of exercise on weight loss and monocytes in obese mice. Comp Med 2012; 62(1):21-6.

29. Viardot A, Lord RV, Samaras K. The effects of weight loss and gastric banding on the innate and adaptive immune system in type 2 diabetes and prediabetes. $J$ Clin Endocrinol Metab 2010; 95(6):2845-50.

30. Bandaru P, Rajkumar H, Nappanveettil G. The Impact of Obesity on Immune Response to Infection and Vaccine: An Insight into Plausible Mechanisms. Endocrinol Metab Synd 2013; 22: 1000113-1000122.

31. Procaccini C, Jirillo E, Matarese G. Leptin as an immunomodulator. Mol Aspects Med 2012; 33: 35-45. 